\title{
Canada opposes harm reduction policies for drug users
}

$\mathrm{F}$ our drug policy groups monitoring international negotiations on reforms to United Nations drug control policies say Canada has joined ranks with China, Egypt, Iran, Pakistan and Russia in aggressively opposing European endorsements of health policies aimed at reducing harms, such as HIV transmission, among drug users.

Canada also opposes the participation of nongovernmental organizations (NGOs) in future UN drug policymaking sessions, observers report from the negotiations in Vienna, Austria.

Those negotiations will culminate in a draft statement in March, outlining a new set of UN principles that will serve to guide talks by world leaders at the UN General Assembly in 2016. A new global drug-control regime will be adopted to replace the 2009 framework at the assembly. The 2009 statement did not endorse harm reduction, but promoted "the war on drugs" policies favoured by US negotiators at the time. European negotiators are pressing to have much stronger emphasis placed on harm reduction in the new statement.

At the latest negotiation session on Jan.14, "Canada once again led the charge" against a UN endorsement for "risk and harm mitigation and reduction measures" according to the International Drug Policy Consortium (IDPC), a UKbased group attending the negotiations. IDPC staff who spoke to $C M A J$ asked not to be named due to concerns they could be barred from observing future negotiations. In a blog report posted after the session, one IDPC observer stated that Canada was "very vocal throughout" the session and opposed any references to the term, "harm reduction."

In what IDPC staff describe as a "fascinating standoff," the European Union, alongside Norway and Switzerland, "have remained adamant that they would not accept any compromise on this language." Negotiators for the US have expressed support for specific interventions such as needle and syringe programs, the IDPC reports, "but not for the term harm reduction."

Rick Lines, executive director at Harm Reduction International, a UK-based group that works with the IDPC, says "To

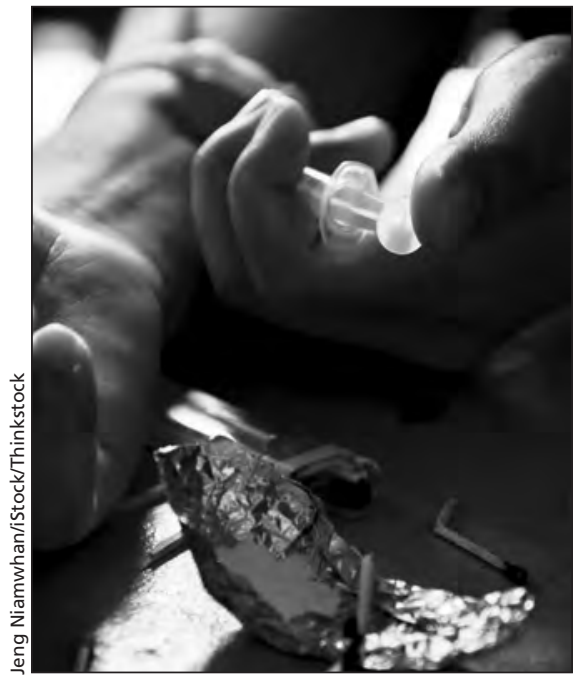

Draft guidelines for a new global drugcontrol regime will be used to replace the 2009 framework that promoted "the war on drugs" policies favoured by US negotiators at the time. European negotiators are urging a stronger emphasis placed on harm reduction in the new statement.

have a federal government get up at international forums and oppose programs that exist at home seems cruel and hypocritical." Lines, who once worked on harm reduction in Canadian prisons, added that "when you oppose harm reduction you inevitably wind up on the same side as Iran, China and Russia."

Beatrice Fenelon, a spokesperson for Canada's Department of Foreign Affairs, Trade and Development, says "the Government of Canada believes that the best way to address the public health consequences of injection drug use is to prevent people from using illicit drugs in the first place." She refused to elaborate. "As negotiations of the ministerial statement for the high-level segment of the UN Commission on Narcotic Drugs are ongoing," she explained, "Canada is not in a position to discuss negotiating positions."

Canada also appears to have reversed its previous stand on including NGOs in its delegation to UN drug-policy negotiations. At the recent session in Vienna, it asked delegates to delete text endorsing "the opportunity for an open, transparent and forward-looking discussion within the multilateral system on these issues," IDPC staff report.

In an earlier session on Dec. 5,
IDPC staff reported that Canada expressed opposition to an endorsement of "civil society engagement in the draft statement."

Don Macpherson, director of the Canadian Drug Policy Consortium, says Canadian negotiators adopted a similar position at drug talks sponsored by the Inter-American Drug Abuse Control Commission, which he attended in Bogota, Colombia in December 2013. "The Canadian negotiators vigorously opposed proposals to expand the discussion of policy reforms," Macpherson says.

Foreign Affairs spokesperson Fenelon explained the tactics taken in Bogota by stating in an email that with the UN talks underway in Vienna "ample opportunities to debate drug policy" have been "programmed into the international agenda, and proposals for still further forums to conduct the same discussion serve to stretch limited resources."

Fenelon insists that Canada has consistently supported "enhanced civil society participation" at the UN talks in Vienna.

Canada's opposition to harm reduction strongly resembles the Russian position, which IDPC Executive Director Ann Fordham described in a Twitter posting on Nov. 5, 2013, as endorsing "the status quo."

As the second-largest donor to UN drug control programs after the European Commission, Canadian negotiators in Vienna can be confident they will be heard.

By supporting Russia's position against harm reduction, Canada is allying with a country where HIV rates among intravenous drug users are as high as 50\%, notes Mikhail Golichenko, a senior policy analyst and lawyer with the Canadian HIV/AIDS Legal Network in Toronto, Ontario.

With an estimated 60000 new HIV infections annually, says Golichenko, "Russia desperately needs to adopt harm reduction measures. Instead, with Canada's support, they are exporting their war on drug users internationally." Paul Christopher Webster, Toronto, Ont.

CMAJ 2014. DOI:10.1503/cmaj.109-4714 